\title{
ЕТИМОЛОГІЯ ПОНЯТТЯ “ЕВРИСТИЧНИЙ ПІДХІД”
}

\author{
Парфентьєва І. П., доктор філософії в галузі освіти, дочент кафедри музичного мистецтва \\ Матвійчук К. О., магістр
}

Украӥна, м. Миколаӥв, Миколаївський національний університет імені В. О. Сухомлинського

DOI: https://doi.org/10.31435/rsglobal_ws/30082018/6078

\section{ARTICLE INFO}

Received: 27 July 2018

Accepted: 25 August 2018

Published: 30 August 2018

\section{KEYWORDS}

heuristics, method of finding, education, pedagogical heuristics.

\begin{abstract}
The article deals with the term "heuristics", which in scientific knowledge has the designation as a "method of finding." The author conducts an analysis of scientific literature on the interpretation of heuristics as a scientific concept. Heuristics as an independent science has not been fully formed yet. Despite the large number of scientific papers devoted to questions of heuristics, they usually relate to its particular problems and do not give a clear idea of either the object or subject of heuristics or its status among other sciences. It is suggested that pedagogical heuristics are defined as one of the branches of heuristics, which studies fundamental principles of didactics and the systematic organization of students' heuristic activity in a supervised interaction of a teacher and implements them in general and in vocational education using the system of problem tasks for the purposeful development of intelligence. The main tasks of pedagogical heuristics interact with the tasks of didactics in the qualitative formation of a future specialist. Therefore, pedagogical heuristics in researches use heuristic methods that allow to accelerate the process of solving any problem.
\end{abstract}

Citation: Парфентьєва I. П., Матвійчук К. О. (2018) Etymolohiia Poniattia "Evrystychnyi Pidkhid” World Science. 8(36), Vol.3. doi: 10.31435/rsglobal_ws/30082018/6078

Copyright: () 2018 Парфентьєва І. П., Матвійчук К. О. This is an open-access article distributed under the terms of the Creative Commons Attribution License (CC BY). The use, distribution or reproduction in other forums is permitted, provided the original author(s) or licensor are credited and that the original publication in this journal is cited, in accordance with accepted academic practice. No use, distribution or reproduction is permitted which does not comply with these terms.

Термін «евристика» у науковому пізнанні має позначення як «метод знаходження». Підвалини цього методу закладалися ще у давній філософії. У Древній Греції це слово означало «метод навчання». Він застосовувався Сократом, який змушував співрозмовника діяти евристичними методами досягнення цілей. Архімед, який заклав основи теорії знаходження вирішення нових завдань, розробив евристичні процедури аналізу та синтезу. Німецький філософ Г. Лейбніц займався науковою діяльністю, яка була спрямована на те, щоб спонукати людину до відкриття і винаходу. В його працях містяться численні фрагменти, що описують організацію творчості. Це фактично різноманітні евристичні прийоми, які допомагають знаходженню шляхів вирішення нових завдань. Французький вчений А. Сен-Симон приділяв багато уваги дослідженню порівняння як важливого пізнавального засобу. Він висунув ідею створення особливої науки про порівняння ідей, вказуючи в якості зразка для неї на математику. У XIX ст. порівняльний метод отримав широке застосування в різних науках.

Значний інтерес для визначення суті евристики представляють ідеї чеського логіка, математика i філософа Б. Больцано, де вчений показав, що посилання на будь-якого роду очевидність не може служити доказом в науковому дослідженні; усі помилки виникають 3 того, що неправильно оцінюється вірогідність евристичних висновків i часто ці висновки використовуються як докази. Багато уваги питанням евристики приділяв французький математик А. Пумнкаре. Він вважав, що, спостерігаючи за творчістю математика, можна проникнути в саму суть людського розуму, вивчити психологічний механізм творчості. 
Цінність робіт по евристиці А. Пумнкаре в тому, що проблеми евристики ним викладені на основі власного досвіду.

Вже в першій половині XX ст. з'явилися роботи з проблем евристичної діяльності у певних наукових сферах. Так, П. Енгельмейєр опублікував «Теорію творчості», в якій розробив загальні питання створення цілої науки про творчість, - еврології, підкреслюючи єдність евристичних i логічних початків цієї науки. Єдиний органічний процес творчості П. Енгельмейєр розділяв на три якісно відмінних акти: задум, план, реальний вчинок.

Наукова література не має однозначного тлумачення евристики як наукового поняття. В роботах Р. Перельмана 3 інтенсифікації науково-технічної творчості це поняття ототожнюється 3 психологією наукової творчості: «Психологія наукової творчості - евристика - вивчає, як вирішуються наукові задачі, що вимагають, окрім знань та вмінь, ще й кмітливості, здогадки». Психолог Я. Пономарьов стверджує, що евристика — це «абстрактно-аналітична наука, що вивчає один з структурних рівнів організації творчої діяльності та іiі продуктів». [5] Український радянський енциклопедичний словник дає такі визначення евристики, як: спеціальні методи, що використовуються в процесі відкриття (створення) нового (евристичні методи); наука, що вивчає продуктивне та творче мислення (евристичну діяльність). [8] Психолог В. Пушкін вважає, що евристика - це «галузь знання, що вивчає формування нових дій в незвичайній ситуації», вона може бути наукою тільки в тому разі, якщо евристичні процеси, що призводят до цих нових дій, знайдуть нарешті свій математичний опис. [6]

Наведені концепції, які, звичайно, не є вичерпними, свідчать про те, що евристика як самостійна наука ще не до кінця сформувалася. Незважаючи на велику кількість наукових праць, що присвячені питанням евристики, вони, як правило, стосуються їі окремих проблем, i не дають чітких уявлень ні про об'єкт та суб'єкт евристики, ні про іiі статус серед інших наук. Нами виявлено, що в роботах Г.Буша та К.Буша простежується спроба узагальнення численних концепцій та формулювання на цій основі визначення статусу та предмету евристики. За визначенням вчених, евристика - «це загальнонаукова теорія вирішення проблемних задач, що виникають у людській діяльності та спілкуванні». А предметом іiі, відповідно, є «виявлення, обробка та впорядкування закономірностей, механізмів та методологічих засобів антиціпації (передбачення) та конструювання нового знання та цілеспрямованих способів діяльності та спілкування, що створюються на основі узагальнення наявного досвіду та випереджуючого відображення моделей майбутнього з метою повнішого задоволення потреб людей».

У філософському енциклопедичному словнику пропонується трактування евристики як “науки, що вивчає творчу діяльність, методи, що використовуються у відкритті нового і в навчанні. Призначенням евристики є побудова моделей процесу вирішення нової задачі. Евристика - наука про виникнення нового в знанні і діяльності людини. У завдання евристики входить розробка засобів управління евристичними процесами, вивчення умов формування здібностей до творчої інтелектуальної діяльності і методів її організації” [9].

Махмутов М. Виокремлює творчість як евристичну діяльність, сутність якої полягає в швидкому розумінні, схоплюванні основної ідеї, суті поняття в раптовому знаходженні прийому дії або образу. [3] Математик Д. Пойа вважає, що предмет евристики “переплітається 3 іншими науками; іii окремі частини належать не тільки математиці, але і логіці, педагогіці i навіть філософії, мета евристики - досліджувати методи і правила, як робити відкриття i винаходи". [4] Психолог К. Роджерс. розглядаючи психологічну теорію прийняття рішень евристичну діяльність ототожнює 3 системою правил, інструкцій або 3 інтуітивними міркуваннями [7] А. Хуторськой розглядає евристику як спрямованість діяльності людини, орієнтовану на створення ним суб'єктивно або об'єктивно нового і значущого продукту [10].

Можна зробити висновок, що педагогічна евристика визначається як одна 3 гілок евристики, яка вивчає принципові закономірності дидактики і системної організації евристичної діяльності студентів в керованій педагогом взаємодії і реалізує їх загалом і в професійній освіті 3 використанням системи проблемних завдань для цілеспрямованого розвитку інтелекту. У якісному становленні майбутнього фахівця основні завдання педагогічної евристики взаємодіють із завданнями дидактики. Тому педагогічна евристика використовує як евристичні, так і дидактичні методи у дослідженнях.

Евристика нерозривно пов'язана з творчою діяльністю. Творчість та евристику в єдине ціле збирають уявлення про нетривіальність, неординарність, новизну та унікальність. Стосовно поняття «творчість», такими якостями характеризується результат творчої діяльності, а стосовно евристики — методи та засоби отримання цього результату. 
А.Хуторський виокремлює основне завдання евристичних методів навчання створення нових освітніх результатів:ідей, творів, досліджень, конкурсів, художніх творів та ін. В евристичному навчанні, що спирається на поняття індивідуальної освітньої траєкторії, підхід до оцінки навчальних результатів перевіряється не тільки ступенем досягнення студентами зовнішніх заданих результатів, а і «творчим відхиленням» від них. Основний параметр оцінки особистісних освітніх результатів - ступінь комплексного освітнього зростання студента, що включає як стандартні, так і індивідуальні параметри.

Евристичний підхід до навчання відрізняється тим, що не задає готового предметного змісту як результат вивчення курсу чи теми, але вимагає від студента в ході навчання створення нового змісту, тобто його власного зростання.

Парадигма евристичного навчання як інноваційної освітньої технології склалася у зарубіжній і вітчизняній педагогіці завдяки дослідженням К. Роджерса, А. Маслоу та його школи, В. Пушкіна, В. Андреєва, В. Алфімова [1], М. Лазарєва, В. Лозової, С. Сисоєвої, В. Сологуба, А. Хуторського.

Евристична діяльність студента забезпечує його самоактуалізацію. Проектування i реалізація власної освіти, розкриття творчого потенціалу можливі лише в його діалозі з зовнішнім мистецько-освітнім середовищем. Смисли і цілі сучасної вищої музично-педагогічної освіти такі, що iii зміст $\epsilon$ педагогічно адаптованим соціальним досвідом, переданим студентам. Вони застосовують знання й уміння, які передаються ззовні, за зразком. Передавальний характер змісту освіти неефективний для розвитку особистісного потенціалу людини, яка навчається і належить до певної культури, не сприяє їі повноцінному творчому формуванню.

У реформованому освіту зростає роль евристичного навчання, під яким розуміється освітня діяльність студентів 3 конструювання ними власного сенсу, цілей, змісту та організації освіти. Поширена думка про те, що творчість напряму залежить від отримання від викладача всіх необхідних для цього знань і вмінь, спростовується фактами, що приводяться вченими і педагогами.

Людина, яка навчається, буде рухатися по індивідуальної траєкторії в усіх освітніх областях у тому випадку, якщо йому будуть надані можливості:

- визначати індивідуальний зміст вивчення навчальних дисциплін;

- ставити власні цілі у роботі над конкретною темою або розділом;

- вибирати оптимальні форми і темпи навчання;

- застосовувати ті способи навчання, які найбільш відповідають його індивідуальним особливостям;

- здійснювати рефлексію своєї освітньої діяльності.

Створення студентом власного освітнього продукту можливе за умови оволодіння ним креативними, когнітивними і організаційними навичками.

При здійсненні цих видів освітньої діяльності виявляються відповідні їм якості особистості:

1) когнітивні (вміння відчувати мистецькі образи, задавати питання, відшукувати причини недоліків, позначати своє розуміння або нерозуміння проблеми та ін.);

2) креативні (натхненний, фантазія, гнучкість розуму, чуйність до протиріч; розкутість думок і почуттів, рухів; прогностичність, наявність своєї думки та ін.);

3) організаційно-діяльнісні (усвідомлення цілей творчої діяльності і готовність їх пояснити; вміння поставити мету і організувати іiі досягнення; здатність до творчості; рефлексивне мислення та ін.).

Евристичний метод полягає у взаємодії викладача й студентів на основі створення інформаційно-пізнавальної суперечності між теоретично можливим способом вирішення проблеми і неможливістю застосувати його практично, з метою організації самостійної роботи студентів щодо засвоєння частини програми за допомогою проблемно-пізнавальних завдань. Викладач, визначивши обсяг, рівень складності навчального матеріалу, викладає його матеріал у формі евристичної бесіди, дискусії чи дидактичної гри, поєднуючи часткове пояснення нового матеріалу з постановкою проблемних питань, пізнавальних завдань чи експерименту. Це спонукає студентів до самостійної пошукової діяльності, оволодіння прийомами активного творчого спілкування, постановки й вирішення навчальних проблем.

Важливо при цьому пояснити матеріал, який студенти не можуть засвоїти самостійно, формуючи високий дослідницько-логічний рівень проблемності, властивий діяльності в новій ситуації, коли алгоритм дії невідомий. У такій діяльності мають переважати логічні процедури аналізу, порівняння, узагальнення.

Узагальнюючи вищесказане, можна зробити висновок, що в евристичному навчанні студенти за допомогою викладача або самостійно створюють свій власний творчий освітній продукт - знання. Вони формулюють власну освітню проблему, мету, завдання освітнього процесу. 


\section{ЛIТЕРАТУРА}

1. Алфімов В. М. Поняття технічної обдарованості та їі складові / В. М. Алфімов // Педагогіка формування творчої особистості у вищій і загальноосвітній школах. - 2016. - Вип. 50. - С. 47-54

2. Каган М. С. Про педагогічний аспект теорії діалогу / / Діалог в освіті: Зб. матеріалів конф. Серія "Symposium". Вип. 22. СПб., 2002, с. 51

3. Махмутов М. И. Вопросы организации проблемного обучения / М. И.Махмутов - Казань : Издательство Казанского университета, 1997. - 64 с.

4. Пойа Д. Как решать задачу / Д.Пойа. - Львов : журнал «Квантор», 1991. - 214 с.: ил.

5. Пономарев Я. А. Психология творчества и педагогика. М., Педагогика, 1976.

6. Пушкін В.Н.Эвристика - наука о творческом мышлении. 1967

7. Роджерс К. Взгляд на психотерапию. Становление человека / К.Роджерс. - М., 1994. - С.23

8. Український Радянський Енциклопедичний Словник: в 3 т. Т.1. А - Калібр / Редкол.: Гол.ред. Федір Семенович Бабичев . - 2-ге вид . - Київ : Українська Радянська Енциклопедія, 1986 . - 751 с. : 35 л. іл., карт. - На укр. яз.

9. Философский энциклопедический словарь / [редкол. С.С.Аверинцев]. - 2-е изд. - М.: Сов. энциклопедия, 1989. - $815 \mathrm{c}$.

10. Хуторской А. В. Дидактическая эвристика. Теория и технологии креативного обучения / Хуторской Андрей Викторович. - М. Издательство Московского университета, 2003. - 415 с 